\title{
The Position of Similar Fact Evidence in Malaysia
}

Ramalinggam Rajamanickam1
Saw Wei Siang ${ }^{2}$
Anisah Che Ngah ${ }^{3}$
Rizal Rahman ${ }^{4}$
1'Lecturer, Faculty of Law, Universiti Kebangsaan Malaysia (UKM), 43600 Bangi, Selangor Darul Ehsan, Malaysia
rama@ukm.edu.my
2Undergraduate Student, Faculty of Law, Universiti Kebangsaan Malaysia (UKM), 43600 Bangi, Selangor Darul Ehsan, Malaysia
${ }^{3}$ Associate Professor, Faculty of Law, Universiti Kebangsaan Malaysia (UKM), 43600 Bangi, Selangor Darul Ehsan, Malaysia
anisah@ukm.edu.my
4Senior Lecturer, Faculty of Law, Universiti Kebangsaan Malaysia (UKM), 43600 Bangi, Selangor Darul Ehsan, Malaysia
noryn@ukm.edu.my

\section{Doi:10.5901/mjss.2015.v6n4p539}

\section{Abstract}

Generally, evidence of bad character of a person especially accused in a case cannot be tendered as it is inadmissible. However, there are few situations where the evidence of bad character may be adduced as relevant in a case if it is provided under the ambit of Evidence Law. Among others, similar fact evidence may be given in a case although it will amount to a bad character of the accused. This article addresses the issue of relevancy of similar fact evidence in Malaysia by referring to the provisions under the Evidence Act 1950 and the decided cases. This article further explains the factors to be considered by the courts before admitting similar fact evidence against the accused in Malaysia. The article found that "striking similarity" which has been used as a main component in admitting similar fact evidence in Malaysia has been relaxed by the Malaysian apex court in the case of Public Prosecutor v Mohamad Roslan bin Desa. The article also found that though the Evidence Act 1950 does not contain any direct provisions relating to similar fact evidence, sections 14 and 15 have been used as similar fact provisions in Malaysia.

Keywords: admissibility; bad character; evidence law; relevancy; similar fact evidence

\section{Introduction}

The general principle in the law of evidence is that all evidence of res inter alios acta nocere non debet are inadmissible (Halsbury's Laws of Malaysia, 2011, para [500.093]-[500.098]). Literally, this Latin maxim means that a transaction between strangers ought not to injure another party; evidence given in other cause between other parties cannot be made available to the present cause because they have nothing to do with the present dispute (Dimond $v$ Lovell [2000] 2 All ER 897, p. 906). This maxim is true and equally applicable for similar transactions inter partes (S. V. Joga Rao, 2001, p. 746).

This principle is said to be 'one of the most deeply rooted and jealously guarded principles of our criminal law and to be fundamental in the law of evidence' (Maxwell v Director of Public Prosecutions [1935] AC 309, p. 317 - Lord Sankey LC). There are, however, exceptions to the general rule which commonly referred to as 'similar fact evidence' under the Evidence Act 1950 (Act 56).

\section{Research Methodology}

The research is pure legal research whereby it focuses on the relevancy and admissibility of similar fact evidence in Malaysia. Therefore, the materials for this research are mainly collected through primary legal sources such as statute and cases. The relevant provisions in the Malaysian Evidence Act 1950 and decided cases including English cases are referred to get a reliable data. The method of contents analysis is used as the methodology in this research. The relevant sections and cases in the Malaysian Evidence Act 1950 are critically analyzed in order to get a sound finding. 


\title{
3. Relevancy of Similar Fact evidence
}

The general principle relating to the inadmissibility of evidence of res inter alios acta nocere non debet was spelt out in the most quoted passage in Makin v Attorney General for New South Wales [1894] AC 57 (PC) by Lord Herschell LC:

'It is undoubtedly not competent for the prosecution to adduce evidence tending to shew that the accused has been guilty of criminal acts other than those covered by the indictment, for the purpose of leading to the conclusion that the accused is a person likely from his criminal conduct or character to have committed the offence for which he is being tried.' (emphasis added) ([1894] AC 57 (PC), p. 65).

In the Makin case, the accused was indicted for murdering an infant. The point of law which was forcefully argued before Their Lordships was that whether the fact that there were several infants found buried in the accused's backyard under the similar circumstances was admissible as evidence against the accused. Their Lordships held that the evidence was admissible:

'On the other hand, the mere fact that the evidence adduced tends to shew the commission of other crimes does not render it inadmissible if it be relevant to an issue before the jury, and it may be so relevant if it bears upon the question whether the acts alleged to constitute the crime charged in the indictment were designed or accidental, or to rebut a defence which would otherwise be open to the accused.' (emphasis added) ([1894] AC 57 (PC), p. 65).

This passage of judgment by the Privy Council was referred and cited with approval by the Supreme Court, the apex court in Malaysia back then in Junaidi bin Abdullah v Public Prosecutor [1993] 3 MLJ 217, p. 225. Though generally the similar fact evidence is more often seen in criminal cases, it is also applicable in civil cases (O'Brien $v$ Chief Constable of South Wales Police [2005] UKHL 26 (HL), cited in CGU Insurance Bhd v Asean Security Paper Mills Sdn Bhd [2006] $3 \mathrm{MLJ} 1$ (CA), para 39). The rationale behind the exclusion of such evidence is that the evidence must be strictly confined to the point in issue and no reference should be made to any other conducts of the accused (or defendant in civil cases) unconnected to the charge (Kennedy $\mathrm{J}$ in $R \vee$ Bond [1906] 2 KB 389, p. 397). Similar fact evidence is an exception to the general rule.

\section{Position of Similar fact Evidence in Malaysia}

Although Makin case was instrumental in the application of similar fact evidence, an important development on the similar fact evidence was the decision of the House of Lords in Boardman v Director of Public Prosecutor [1974] 3 All ER 887. In Boardman case, the accused was charged with buggery and inciting buggery. The question was whether the evidence given in the first charge can be used against the accused in the second charge and vice versa. Lord Wilberforce put forward the principle as follow:

\begin{abstract}
'Whether in the field of sexual conductor otherwise, there is no general or automatic answer to be given to the question whether evidence of facts similar to those the subject of a particular charge ought to be admitted. In each case it is necessary to estimate (i) whether, and if so how strongly, the evidence as to other facts tends to support, i.e. to make more credible, the evidence given as to the fact in question; (ii) whether such evidence, if given, is likely to be prejudicial to the accused. Both these elements involve questions of degree.' ([1974] 3 All ER 887, p. 896).
\end{abstract}

This formulation changes the emphasis of law in admitting evidence of similar fact. It was no longer that to rebut a defence but it is its probative value and prejudicial effect that ought to be given utmost consideration. In determining whether a similar fact is admissible, the test is that its probative force must override its prejudicial effect. In Public Prosecutor $v$ Veeran Kutty, Peh Swee Chin J quoted in favour of the formulation in Boardman case and of the view that Boardman case is applicable in Malaysia because it has merely modified the ratio in the Makin case (Public Prosecutor $v$ Veeran Kutty [1990] 3 MLJ 498, p. 504).

The 'probative force and prejudicial effect test' was also adopted by the Supreme Court in Junaidi bin Abdullah v $P P$ where Mohamed Azmi SCJ in delivering the judgment of the court, considered both cases and held that:

"On the principle laid down in Makin's case and Boardman's case, we are of the opinion that where the purpose of adducing evidence of similar facts or similar offences is justifiable on the ground of relevancy and necessity to rebut any defence which would otherwise be open to the accused (in addition to those under ss14 and 15 of the Evidence Act 1950), it is admissible in evidence provided the probative value of such evidence outweighs its prejudicial value. There 
must be a real anticipated defence to be rebutted and not merely 'crediting the accused with a fancy defence" ([1993] 3 MLJ 217, p. 226).

However, it is pertinent to note that the test in the Boardman case is a general one and not restricted to a particular manner. As Lord Mackay of Clashfern said in Director of Public Prosecutions v P [1991] 2 AC 447 [hereinafter "DPP v $P$ "], it is not appropriate to single out 'strikingly similarity' as an essential element in every case because the essential feature of similar fact evidence is that its probative force overriding its prejudicial effect ([1991] 2 AC 447, p. 460).

\subsection{Relevant Provisions under the Malaysian Evidence Act 1950}

The similar fact evidence is provided under ss. 14, 15 and arguably $11(b)$ of the Malaysian Evidence Act. There is no difficulty to classify ss. 14 and 15 as similar fact evidence. However, as far as s. 11(b) is concerned, there are different opinions on whether this section accommodates similar fact evidence.

\subsubsection{Section 11(b)}

In RV Raju \& Ors v R [1953] MLJ 21 at p. 22, Spenser Wilkinson J was of the opinion that although evidence of similar fact is often admissible under s. 15 of the then Evidence Ordinance, they may be admissible under ss. 11 and 14 (see also Kan Sik Fong v Public Prosecutor [1961] MLJ 163). Several prominent local authors hold the same view (Rafiah Salim, 1989, p. 215; Hamid Sultan, 2014, p. 288). On the other hand, Augustine Paul argued that s. 11(b) is incapable of accommodating evidence of similar facts (Augustine Paul, 2003, p. 113). Similarly, Jeffrey Pinsler by referring to the commentary by the framer of the Evidence Act, contended that s. 11(b) was not intended to introduce similar fact evidence (J. Pinsler, 1999, p. 54-55).

It is argued that the views of Augustine Paul and Jeffrey Pinsler represent a better view simply because s. 11(b), from the wording itself was intended as a residuary section. Similar fact evidence is relevant under ss. 14 and 15; therefore, following the argument of the learned authors, s. 11(b) cannot be said to have the effect to reinforce the law of relevancy by rendering relevant what has already been declared relevant.

\subsubsection{Section 14}

Sections 14 and 15 of the Malaysian Act are closely related. Section 14 has a wider application compared to s. 15 because under the latter, the facts sought to be proved must form part of a series of similar occurrences (Augustine Paul, 2003, p.126).

Under s. 14, facts showing (i) the existence of any state of mind; or (ii) the existence of any state of body or bodily feeling are relevant and admissible. The illustrations under the said section are self-explanatory as to the application of the section. In Re Soo Leot [1956] MLJ 54, it was held that hearsay evidence is also admissible under this section though the probative value of such evidence is discounted (1956] MLJ 54, p. 56). Furthermore, s. 14 may be resorted to render facts which show or establish intention (X v Public Prosecutor [1951] 2 MLJ 141); negligence (Ngooi Lee Jin v R [1941] MLJ 3); intoxication (Saw TheanTeik v R [1953] MLJ 124); or knowledge (Abubakar bin Ismail v R [1954] MLJ 67) relevant.

\subsubsection{Section 15}

Section 15 of the Malaysian Act is another exception to the general principle that all evidence of res inter alios acta nocere non debet is not admissible. Section 15 renders facts which may decide whether an act was accidental or intentional or done with a particular knowledge relevant. Nonetheless, it is required that the evidence of other facts tendered must be of the same specific kind as that in question (Augustine Paul J in Public Prosecutor v Dato' Seri Anwar bin Ibrahim (No. 3) [1999] 2 MLJ 1, p. 175-176).

Section 15 can be invoked to introduce similar facts to prove the intention of an accused when mens rea is the essential element of an offence and also to rebut the defence (Terrell Ag CJ in VKSSamy $v R$ [1937] MLJ 172, p. 173). Similarly, evidence of modus operandi can be admitted to rebut a defence (Suffian LP in Datuk Haji Harun bin Haji Idris $v$ Public Prosecutor [1977] 2 MLJ 155, p. 172-173). However, it is pertinent to note that evidence of past criminal activities is not admissible if the similar fact evidence plainly tended to show that the accused had been guilty of criminal acts other than that with which they are charged, for the purpose of leading to the conclusion that they were persons likely from their 
criminal conduct or character to have committed the offence for which they were being tried (Poon Soh Har \& Anor $v$ Public Prosecutor [1977] 2 MLJ 126, p. 127).

\subsection{Latest Development}

In many Malaysian cases, curiously, the courts rarely make reference to the Malaysian Act in admitting similar fact evidence. One author has actually urged the courts to refer to ss. 14 and 15 rather than relying too much on the English law principles (Norbani, 1994). In Azahan Bin Mohd Aminallah v Public Prosecutor [2005] 5 MLJ 334, the Court of Appeal held that the balancing exercise by weighing the probative value of such evidence against its prejudicial effect is impliedly required by ss. 14 and 15 of the Evidence Act 1950. The court held that Ss. 14 and 15 of the Evidence Act should be governed by the test adopted by the Boardman case ([2005] 5 MLJ 334, para 21; Al Bakhtiar bin Ab Samat v Public Prosecutor [2012] 4 MLJ 713 (CA); Mohammad bin Abdullah v Public Prosecutor [2011] 4 MLJ 549).c

The 'probative value and prejudicial effect test' also found its favour in the Federal Court in Public Prosecutor $v$ Mohamad Roslan bin Desa (Criminal Appeal No 05-28 of 2007 (K), Federal Court (unreported). In that case, the court below i.e. the Court of Appeal rejected evidence of similar fact because they found that there is no 'striking similarity' (See the judgment of the Court of Appeal in Public Prosecutor v Mohd Roslan bin Desa \& Anor [2011] 4 MLJ 826). In overruling such a view, Ariffin bin Zakaria CJ (Malaya) held that:

'The test has since been authoritatively laid down by $D P P \vee P$ in terms of probative value as against its prejudicial effect. There is force in saying that the decision in Deputy Public Prosecutor $v P$ is in line with ss. 14 and 15 of the Evidence Act as 'striking similarity' has never been a requirement of the said sections.' (emphasis added) (Criminal Appeal No 05-28 of 2007 (K), Federal Court (unreported), para 26)

\section{Result and Discussion}

Based on the explanation above, it is submitted that although similar fact evidenve is admissible under the Malaysian Evidence Law but none of the provisions in the Malaysian Evidence Act 1950 directly address the relevancy of similar fact. It is argued that sections 11 (b), 14 and 15 of the Evidence Act 1950 can be interpreted as provisions regulating the relevancy of the similar fact evidence in Malaysia. However, some authors believe that section 11 (b) is not related to similar fact evidence as this section provides the relevancy of residuary facts. To a certain extent, the authors agree with the argument that section 11 (b) is not connected to similar fact evidence because it provides the relevancy of residuary facts.

This statement may be further proved by looking into the decided cased as quoted above. The judges in those cases only quoted sections 14 and 15 of the Evidence Act 1950 in admitting the similar fact evidence in Malaysia (see, for instance, the cases such as in Junaidi bin Abdullah v PP [1993] 3 MLJ 217; Public Prosecutor v Mohamad Roslan bin Desa, Criminal Appeal No 05-28 of 2007 (K), Federal Court (unreported); Azahan Bin Mohd Aminallah v Public Prosecutor [2005] 5 MLJ 334). If section 11(b) is relevant to similar fact evidence, definitely the judges have quoted the section as well. On the other hand, there are several decided cases that have quoted setion $11(\mathrm{~b})$ in discussing about similar fact evdience such as RV Raju \& Ors v R [1953] MLJ 21 and Kan Sik Fong v Public Prosecutor [1961] MLJ 163. However, there is no clear guidelines from the Malaysian courts as to the relevancy of similar fact evidence under section 11(b).

Another important issue with respect to similar fact evidence is the factors to be considered in deciding whether a fact is similar to other facts before a court may admit it as similar fact evidence. After the decision of Federal Court in Public Prosecutor v Mohamad Roslan bin Desa, it is crystal clear that "striking similarity" is no more a sole factor or crucial element in admitting similar fact evidence. According to the court, 'striking similarity' has never been a requirement of sections 14 and 15 of the Malaysian Evidence Act 1950. The question arise here is what are the factors or elements to be used by the courts in admitting a fact as similar fact evidence. If 'striking similarity' is not a requirement under section sections 14 and 15, how will the courts determine the similarity of two or more facts adduced as similar fact evidence in Malaysia. It is submitted that there should be proper guidelines pertaining to this issue, so that there will be clarity for the players in the legal field.

\section{Conclusion}

The law concerning the admissibility of evidence of res inter aliosactanocere non debet in Malaysia can be summarised into several stages. Firstly, the Malaysian courts followed Makin case which provided exceptions where the evidence is 
relevant to answer the question: firstly, whether the acts alleged to constitute the offence were designed or accidental; or secondly, to rebut a defence which would otherwise be open to the accused. These exceptions are said to be exhaustive in nature.

Secondly, the important development of English law by the House of Lords in Boardman case was followed by the Malaysian apex court in Junaidi case. The 'striking similarity' test enunciated in Boardman case was said to be openended and extend the categorical approach in Makin case to accommodate the peculiarity of each individual case.

Lastly, following the case of DPP v P, the Federal Court in Mohamad Roslan bin Desa pronounced that, though the 'striking similarity' test remains relevant for consideration in admitting evidence, it was no longer the essential requirement under ss. 14 and 15.

Hence, it is safe to conclude that as far as the Malaysian law is concerned, the decisive factor in admitting similar fact evidence is that the probative value (also used interchangeably with 'probative force') of such evidence must override the prejudicial effect against the accused.

\section{References}

Evidence Act 1950

Augustine Paul, (2003) Evidence: Practice and Procedure, $3^{\text {rd }}$ Ed., Malayan Law Journal, Kuala ALumpur

Halsbury's Laws of Malaysia, (2011), Vol 21, Malayan Law Journal, Kuala Lumpur.

Hamid Sultan bin Abu Backer, (2014) The Law of Evidence, $4^{\text {th }}$ Ed., Janab (M) SdnBhd, Kuala Lumpur

J.Pinsler, (1999) Evidence, Advocacy and the Litigation Process, Butterworths, Singapore, 1999.

Norbani bte Mohamed Nazeri, 'Junaidi Bin Abdullah v PP: Principles of Similar Fact Evidence' [1994] 3 Malayan Law Journal ccxxii.

Rafiah Salim, (1989) Evidence in Malaysia and Singapore: Cases, Materials and Commentary, Butterworths, Kuala Lumpur,

S. V. Joga Rao, (2001)Sir John Woodroffe \& Syed Amir Ali's Law of Evidence, 17th ed., Butterworth, New Delhi,

Abu Bakar bin Ismail v R [1954] MLJ 67

Al Bakhtiar bin Ab Samat v Public Prosecutor [2012] 4 MLJ 713 (CA)

Azahan bin MohdAminallah v Public Prosecutor [2005] 5 MLJ 334

Boardman v Director of Public Prosecutor [1974] 3 All ER 887

CGU Insurance Bhd v Asean Security Paper Mills Sdn Bhd [2006] 3 MLJ 1 (CA)

Datuk Haji Harun bin Haji Idris v Public Prosecutor [1977] 2 MLJ 155

Dimond v Lovell [2000] 2 All ER 897

Director of Public Prosecutions v P [1991] 2 AC 447

Junaidi bin Abdullah v Public Prosecutor [1993] 3 MLJ 217

Kan Sik Fong v Public Prosecutor [1961] MLJ 163

Makin v Attorney General for New South Wales [1894] AC 57 (PC)

Maxwell v Director of Public Prosecutions [1935] AC 309

Mohammad bin Abdullah v Public Prosecutor [2011] 4 MLJ 549 (CA)

Ngooi Lee Jin v R [1941] MLJ 3

O'Brien v Chief Constable of South Wales Police [2005] UKHL 26 (HL)

Poon Soh Har \& Anor v Public Prosecutor [1977] 2 MLJ 126

Public Prosecutor v Dato' Seri Anwar bin Ibrahim (No 3) [1999] 2 MLJ 1

Public Prosecutor v Mohamad Roslan bin Desa, Criminal Appeal No 05-28 of 2007 (K), Federal Court (unreported)

Public Prosecutor v Veeran Kutty

$R \vee$ Bond [1906] 2 KB 389

RV Raju \& Ors v R

Saw Thean Teik v R [1953] MLJ 124

VKS Samy v R [1937] MLJ 172

X v Public Prosecutor [1951] 2 MLJ 141 